Historic, archived document

Do not assume content reflects current scientific knowledge, policies, or practices. 

Common Browse Plants

\section{of the Georgia Coastal Plain}

Their chemical composition

and contribution to cattle diet

by

L. K. Halls, F. E. Knox

and V. A. Lazar

SOUTHEASTERN FOREST

EXPER!MENT STATION

Asheville, North Carolina

Joseph F. Pechanec,

Director 


\section{CONTENTS}

$\underline{\text { Page }}$

Introduction ....................... . . . 1

The Experimental Range . . . . . . . . . . . . . . . 2

Browse Collections and Analyses . . . . . . . . . . . 3

Description of Browse Plants . . . . . . . . . . . . 3

Consumption of Browse by Cattle . . . . . . . . . . . . . 9

Chemical Composition of Browse Plants . . . . . . . . . . 9

Crude Protein ................... . . 9 9

Lignin . . . . . . . . . . . . . . . . . . . . 12

Ash ........................... 12

Ether Extract . . . . . . . . . . . . . . . 12

Cellulose and Other Carbohydrates . . . . . . . . . . 12

Mineral Composition of Browse Plants . . . . . . . . . . . 12

Major Elements .. . . . . . . . . . . . . . . 12

Minor Elements................... . 14

Summary .. . . . . . . . . . . . . . . 16

Literature Cited . . . . . . . . . . . . . . . 17 
COMMON BROWSE PLANTS OF THE GEORGIA COASTAL PLAIN:

Their Chemical Composition and Contribution to Cattle Diet

\author{
by \\ L. K. Halls, F. E. Knox, and V. A. Lazar $1 /$
}

\title{
INTRODUCTION
}

The purpose of this paper is to consolidate available information on several important browse plants of the Georgia coastal plain so that their value and over-all contribution to cattle feed can be more fully assessed and compared to other kinds of forage. Numerous observations and notes pertaining to cattle diet were accumulated in the vicinity of the Alapaha Experimental Range, Berrien County, Georgia, from 1942 to 1955. These provided good es timations as to the kind and amounts of browse plants eaten at various times of the year. An indication of the nutritive value of many individual plants was obtained by means of chemical analyses made during these same years. Although chemical analysis is not a specific measure of digestible nutrients, such data signify the approximate food value of a plant.

Browse plants serve a valuable function for cattle grazing in pine forests of the Georgia coastal plain. Not only does browse contribute to the over-all feed supply but it also commonly enhances the nutritional intake of cattle. Certain species are of ten high in a particular plant nutrient or mineral that may be deficient or marginal in other kinds of forage. Too, chemical content of browse generally shows less seasonal fluctuation and crude protein does not decrease during dry periods or during the winter as much as in grasses.

In addition, browse adds variety to cattle diet. Livestock prefer a variety of feed rather than a single species. When permitted to move freely among range types, grazing cattle show a great deal of selectivity and frequently shift from one group of plants to another. This may be prompted by variation in chemical composition, differences in plant taste or smell, or just a natural desire for change.

1) Respectively: Range Conservationist, U. S. Forest Service; Chemist, Agricultural Research Service; and Soil Scientist, U. S. Plant, Soil, and Nutrition Laboratory, Agricultural Research Service. This was a cooperative study between the University of Georgia Coastal Plain Experiment Station, the Forest Service, and the Agricultural Research Service. Both the latter are under the U. S. Department of Agriculture. 
The Alapaha Experimental Range comprises approximately 2800 acres in a forested section of the lower coastal plain of Georgia. Several recognized forest cover types (14) include longleaf-slash pine, slash pine, slash pine-blackgum, and pond cypress. These types intergrade from longleaf pine (Pinus palustris Mill.) $2 /$ on the relatively high, drier ridges to moist areas around swamps and ponds, where slash pine (Pinus elliottii Engelm.) becomes dominant. Still wetter are the shallow ponds and swamps, where pond cypress (Taxodium distichum var. nutans [Ait.] Sweet) predominates. Approximately two-thirds of the area is occupied by longleaf-slash pine and slash pine types and the other third by slash pine-blackgum and pond cypress.

The two most common soils in the longleaf-slash pine and slash pine types are Lynchburg loamy fine sand and Plummer sand. Soils in low moist areas are Rains, Rutledge, and mixed alluvium.

Shrubs constitute about 23 percent of the total understory vegetation beneath the longleaf-slash and slash pine types of the experimental area (fig. 1). Within the slash pine-blackgum and pond cypress types the overhead cover varied from a fairly open condition to a many-layered, dense thicket of shrubs, hardwood trees, and vines.

$\underline{8}$ and $\underline{9}$.

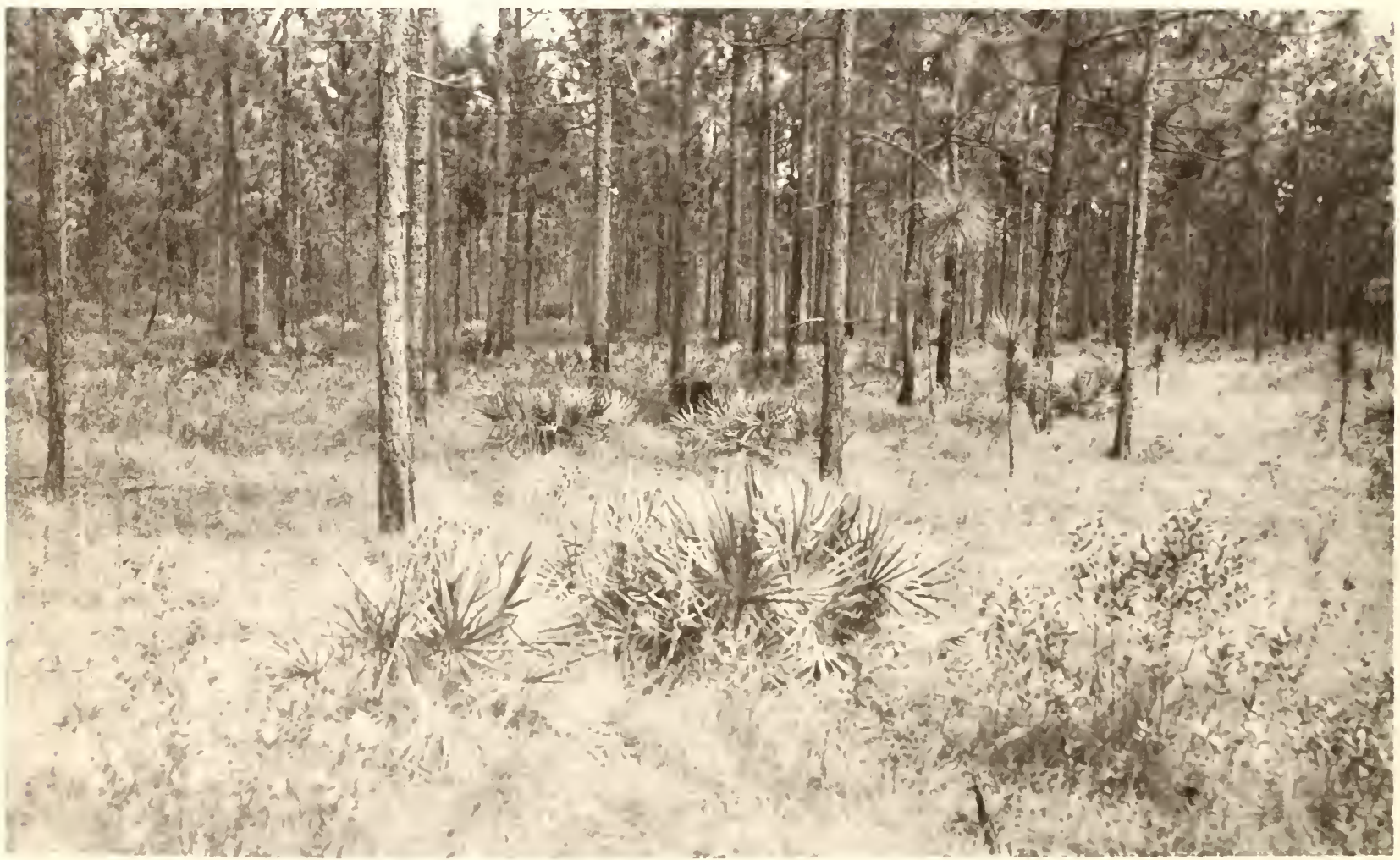

Figure 1. - Sawpalmetto and gallberry are the most prevalent shrubs beneath longleaf and slash pine trees. These and other shrubs constitute about 23 percent of the understory vegetation. 


\section{BROWSE COLLECTIONS AND ANALYSES}

The proportionate amount that browse plants contributed to total cattle diet was estimated in numerous studies from 1943 to 1952 . Frequently dur ing these years, samples of browse were gathered and analyzed for crude protein, calcium, and phosphorus. In 1953 and 1954, a concerted effort was made to further determine the extent that each browse plant was eaten by cattle and to collect samples for chemical analyses during the time of year when the plants were being eaten. When possible, sampling was replicated in two separate ranges.

Collection of browse samples was accomplished while observing the grazing habits of gentle cow herds at various seasons of the year. These cattle moved freely over 300- to 400-acre ranges which supported the cover types previously described. Close scrutiny of the grazing cattle made it possible to ascertain the plant parts and relative amount of particular species eaten. These same portions were then collected from similar plants closeby. Care was exercised to collect the proper ratio of leaves, stems, and shoots. Because diet samples were gathered wherever cows grazed, each sample was a composite of several plants of the same species from different sections of the range area.

Analyses for crude protein, ether extract, ash, calcium, and phosphorus were in accordance with procedures of the Association of Official Agricultural Chemists (2), and cellulose according to Crampton and Maynard (4)). Lignin content was determined in accordance with the methods of Davis and Miller ( $\underline{5})$.

Portions of most plants collected in 1953 and 1954 were further analyzed for the minor elements, copper, iron, manganese, zinc, and cobalt by methods of Parks, et al. (13) and Gregory, et al. (ㅁ) .

A comparison of the nutrient content of browse with that of a composite cattle diet sample consisting of grasses, broadleaved herbs, and browse was made possible through the availability of data obtained in concurrent but separate studies on the same ranges. $3 /$

\section{DESCRIPTION OF BROWSE PLANTS}

Browse consists of twigs, shoots, and leaves of shrubs, trees, or woody vines available for grazing by livestock or game. Growth of this kind is abundant and prolific in the coastal plain. Fourteen such plants are described herein. Each contributed 1 percent or more of the total cattle diet during some porticn of the year (table 1). Pertinent information concerning browse growth habits, occurrence, and season when ordinarily grazed is included below.

3/ Halls, L. K., Hale, O. M., and Knox, F. E. Digestibility and nutrient content of wiregrass forage. 1956. (Manuscript in process of publication.) 
Table 1. - Contribution of browse plants to cattle diet at various seasons of the year (in percent)

\begin{tabular}{|c|c|c|c|c|}
\hline \multirow{2}{*}{ Species } & $:$ & \multicolumn{3}{|c|}{ Ratio of total forage intake } \\
\hline & Spring & Summer & Fall & Winter \\
\hline Red maple & $(\underline{1} /)$ & 1 & -- & -- \\
\hline Red chokeberry & 1 & $(1 /)$ & -- & -- \\
\hline Summersweet clethra & 2 & $(1 /)$ & -- & -- \\
\hline Buckwheattree & $(1 /)$ & 1 & 1 & 1 \\
\hline American cyrilla & 1 & $(1 /)$ & $(\underline{1} /)$ & 2 \\
\hline Bedstraw St. Johnswort & 2 & -- & -- & 1 \\
\hline Gallberry & 1 & $(1 /)$ & -- & - \\
\hline Myrtle dahoon & 1 & $(1 /)$ & 1 & 4 \\
\hline Sweetbay magnolia & 1 & $(1 /)$ & $(\underline{1} /)$ & 3 \\
\hline Blackgum & 2 & 2 & 1 & -- \\
\hline Running oak & $(1 /)$ & $(1 /)$ & $(1 /)$ & - \\
\hline Sawpalmetto & 3 & 3 & 1 & 3 \\
\hline Laurel greenbriar & 1 & $(1 /)$ & -- & 2 \\
\hline Staggerbush & 1 & 1 & (1/) & -- \\
\hline Total & 16 & 8 & 4 & 16 \\
\hline
\end{tabular}

1) Less than 0.5 percent.

Red maple (Acer rubrum L.) is a deciduous tree 80 to 90 feet tall that borders streams, swamps, and upland forests within the slash pine and slash pine-blackgum type. The leaves of small young trees and sprouts at the base of trees are grazed occasionally during the spring and summer.

Red chokeberry (Aronia arbutifolia [L.] Ell.) is commonly found in low moist pine lands and thickets bordering swamps and branches. Cattle graze the young leaves and twigs of this medium sized ( 3 to 10 feet tall) deciduous shrub sparingly in the spring and summer.

Summersweet clethra, or sweet pepperbush (Clethra alnifolia L.), a deciduous shrub, 3 to 10 feet tall, is also found in moist pinelands, thickets bordering swamps and bays, and at the outer edge of swamps. Leaves and young shoot growth are grazed by cattle during the spring. 
Buckwheattree (Cliftonia monophylla [Lam.] Sarg.), locally known as titi, is a large shrub or tree 25 to 30 feet tall, with evergreen leaves. This plant typically forms dense thickets along the borders of swamps and drainageways and is one of the most prevalent hardwoods in the slash pine-blackgum and pond cypress types (fig. 2). The leaves and twigs of this plant are grazed some during the summer, and also during fall and winter when other green forage is scarce.

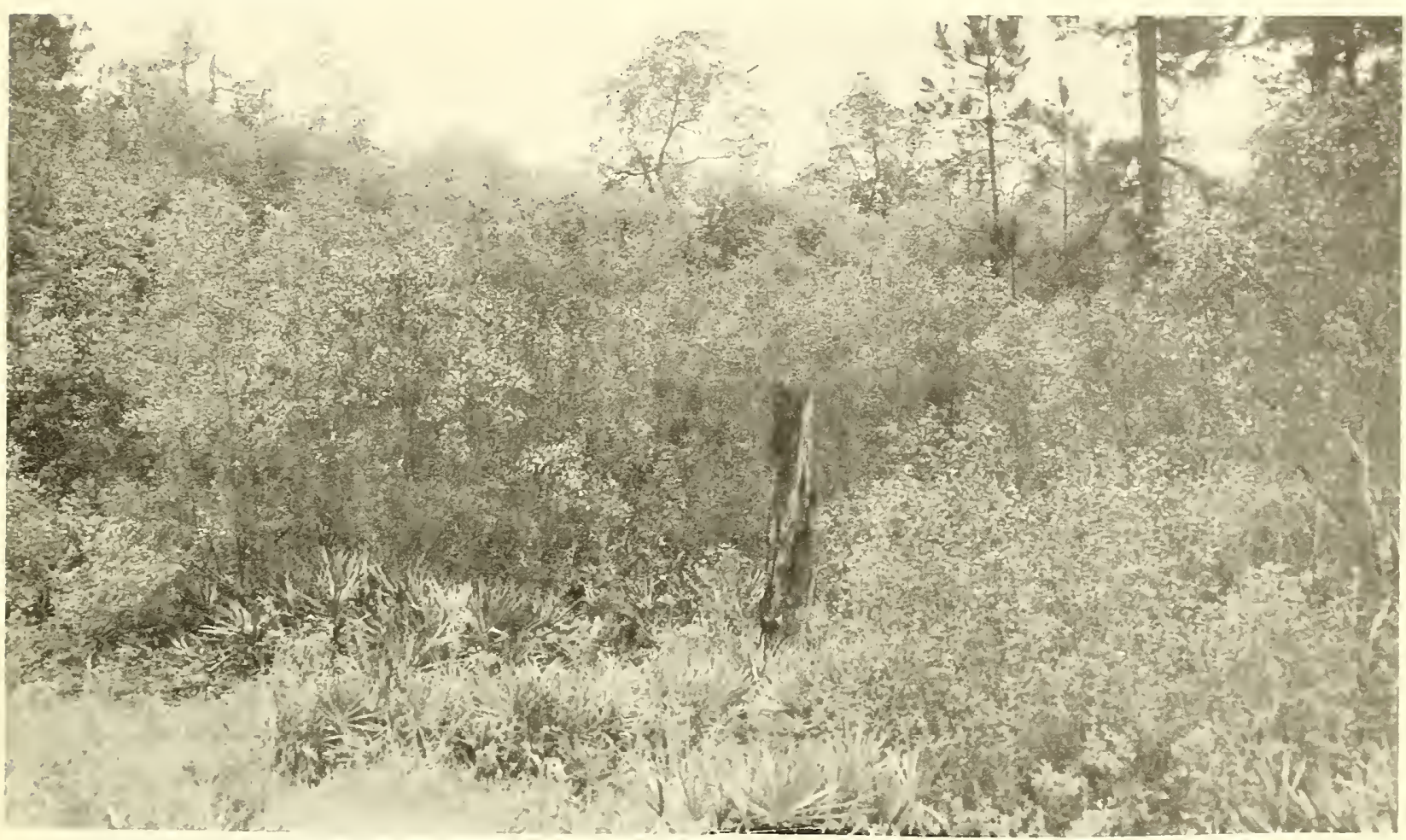

Figure 2.--Buckwheattree and American cyrilla form dense, treelike thickets on borders of swamps and drainageways.

American cyrilla, or ironwood, (Cyrilla racemiflora L.) is associated very closely with buckwheattree. The late-falling leaves give this plant a semi-evergreen appearance. Cattle graze new growth of leaves and twigs in the early spring and consume leaves sparingly through the summer and early fall. Amounts grazed increase during late fall and early winter before the leaves are shed.

Bedstraw St. Johnswort (Hypericum galioides Lam.), an evergreen shrub 2 to 6 feet tall, is commonly found within shallow ponds and wet areas of the pond cypress type and also in low, moist areas adjacent to swamps. The evergreen leaves are grazed during late winter and very early spring.

Inkberry, or gallberry, (Ilex glabra [L.] Gray) occurs extensively in the pinelands and low moist areas and swamps of the coastal plain. This very common evergreen shrub, 1 to 10 feet tall, is very objectionable, as it increases the fire hazard of the forest and reduces growth of herbaceous vegetation. The plant is considered to be unpalatable and of very little use to cattle, but young leaves and sprouts that emerge following a winter fire are grazed very lightly during the spring. 
Myrtle dahoon (Ilex myrtifolia Walt.) has a considerable range in

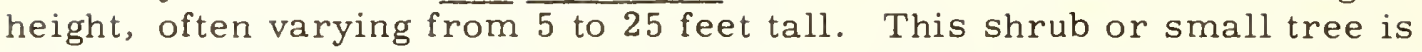
present in nearly all cypress ponds and swamps of the coastal plain. Cattle graze its leaves and twigs more than any other browse species during the winter in the vicinity of the experimental range (fig. 3). On occasion, this member of the holly family is grazed heavily. Cattle have been observed to search out and feed upon this plant for several hours during the day. They may then go several days without grazing it at all.

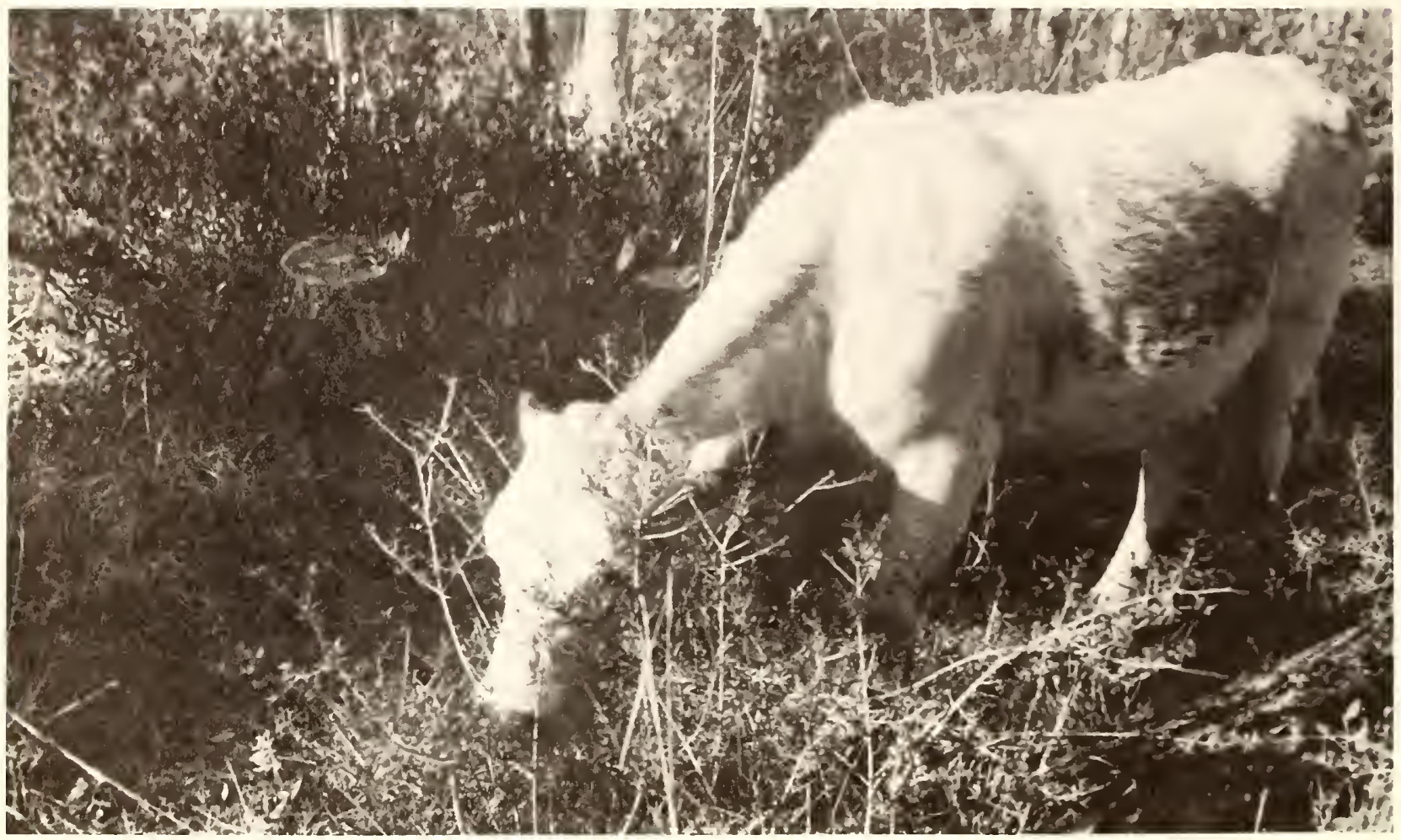

Figure 3.--During the winter, cattle graze the green leaves of myrtle dahoon more than any other browse.

Sweetbay magnolia (Magnolia virginiana L.), a large evergreen shrub or tree 20 to 30 feet tall, occurs widely in the bayheads, swamps, and drainageways of the slash pine and slash pine-blackgum types. Sometimes it forms nearly pure stands. The leaves are grazed considerably during the winter. Young, tender twig and leaf growth is also eaten during spring and early summer.

Blackgum, or black tupelo, (Nyssa sylvatica Marsh.) reaches its greatest importance and is a codominant in the slash pine-blackgum type. This large deciduous tree often attains a height of 50 feet or more. It is found growing on imperfectly drained soils bordering swamps and in swamps where the base of the tree is often inundated for extensive periods in shallow water. After a fire, numerous young shoots emerging from the tree base are quite palatable and are readily eaten by cattle (fig. 4). Leaves and twigs from young trees are eaten consistently by cattle through the spring and summer. 


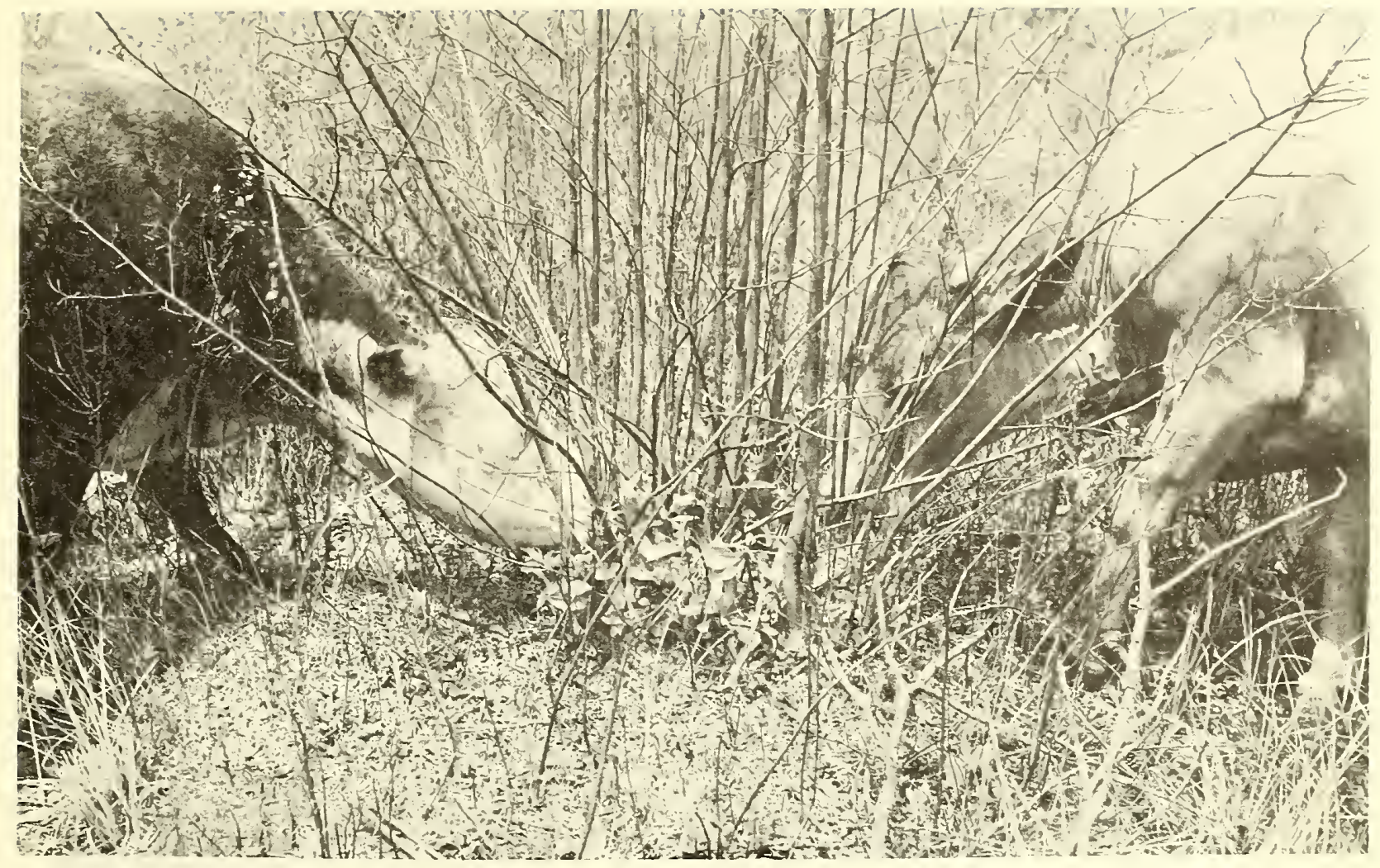

Figure 4.--This young clump of blackgum was burned the previous winter. The following spring, cattle readily ate the young shoots and leaves.

Running oak (Quercus pumila Walt.) frequently forms small sparse thickets in the dry well-drained soils of the longleaf-slash pine forest. Very small amounts of the leaves and twigs of this small ( 1 to 3 feet tall) evergreen shrub are eaten during the spring, summer, and fall.

Sawpalmetto (Serenoa repens [Bart.] Small) assumes several growth habits. The robust stems of this small to large evergreen shrub may be erect or of ten creeping and rooting. Occasionally they have a subterranean habit of growth. Plants often group together to form small to very large colonies on a wide variety of sites ranging from excessively drained sandy ridges to poorly drained swamps. In the vicinity of Alapaha, Georgia, this species is eaten more consistently through the year than any other browse. During the spring and summer, cattle exert considerable energy to tug at and pull out the young center leaves from the stem base (fig. 5). Regrowth of the center leaves may be grazed several times during the year. The outer portions of the tough, fibrous, fan leaves are eaten during the fall and winter.

Laurel greenbriar (Smilax laurifolia L.) is a vigorous, high-climbing, evergreen vine with very sharp spines along the main stem. It often forms large entanglements in the swamps and wet woods of the slash pine-blackgum and pond cypress types. Young tendrils are grazed before the spines have become hardened in the early spring. During the winter, when cattle move through the swamps in search of green feed, the leaves are eaten considerably (fig. 6). 


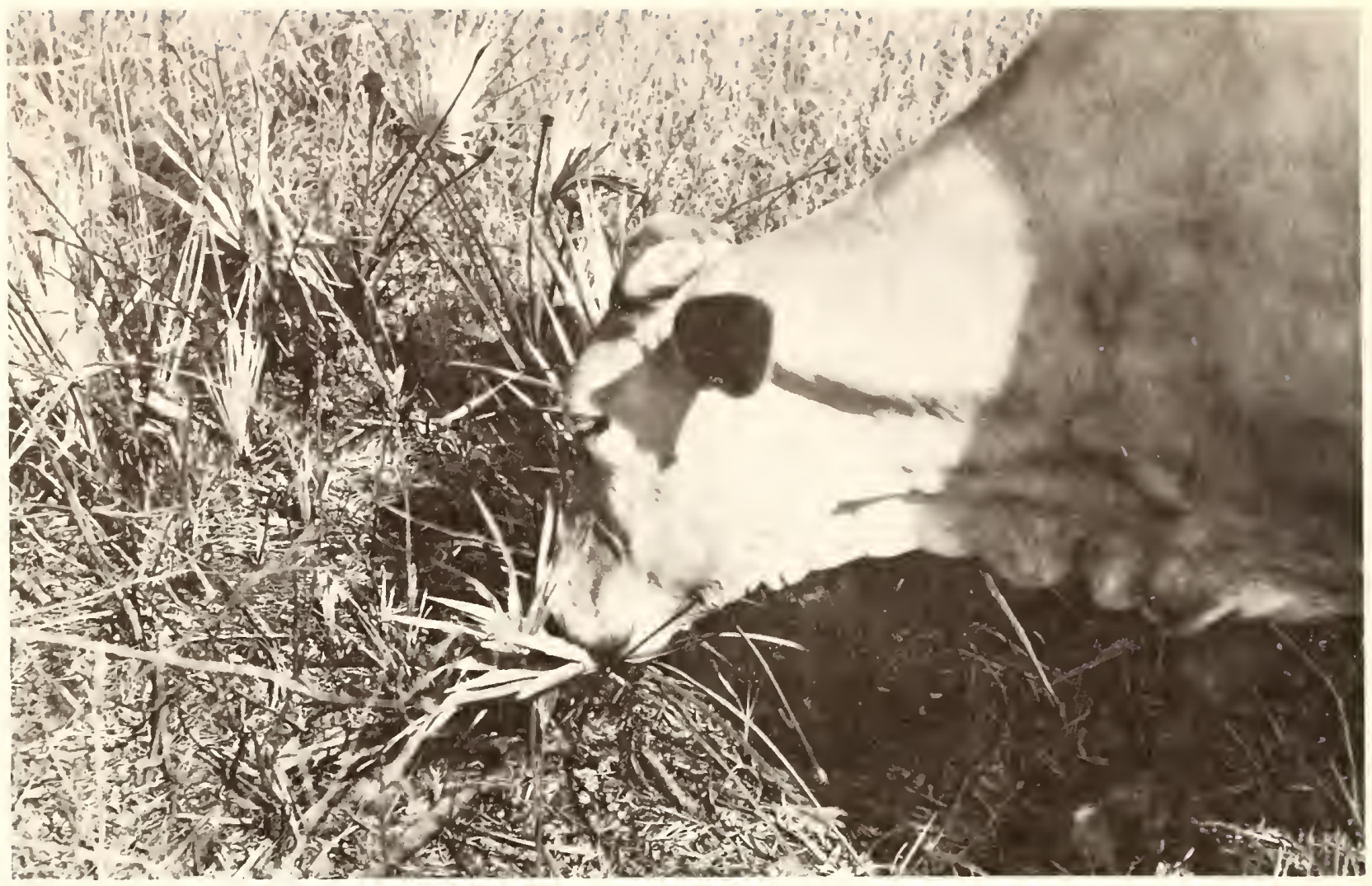

Figure 5.--Sawpalmetto is grazed throughout the year. Young center leaves are eaten consistently during spring and summer. In addition, the outer portion of fan leaves are consumed during the winter.

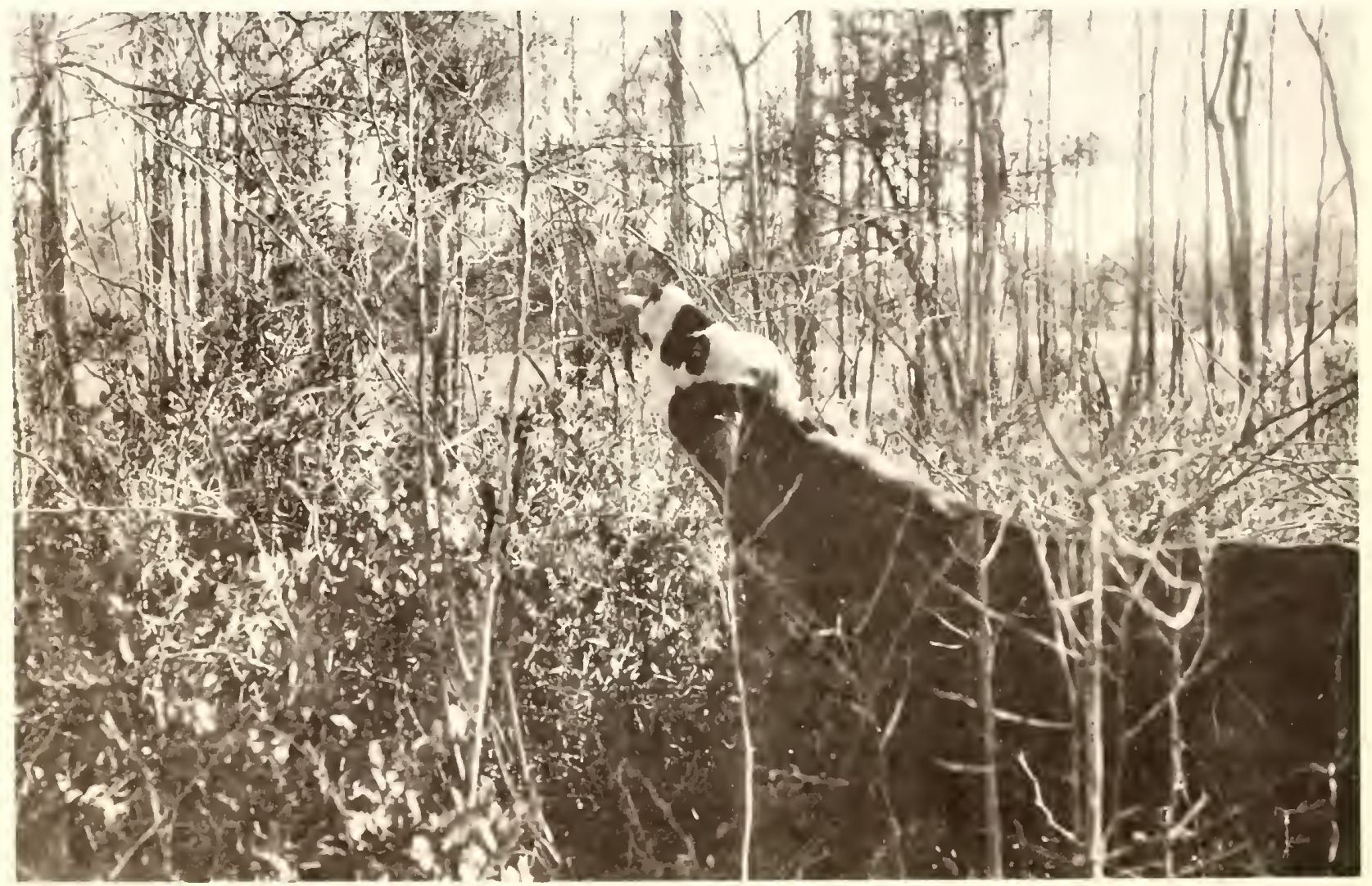

Figure 6. - The leaves of laurel greenbriar furnish feed during the winter and early spring. 
Staggerbush (Xolisma fruticosa [Michx.] Nash) is an evergreen shrub 3 to 10 feet tall. Its occurrence is frequent but scattered throughout the fairly well-drained soils of the longleaf-slash pine type. Current growth of stems and leaves is eaten some during spring and early summer and very sparingly during late summer.

\section{CONSUMPTION OF BROWSE BY CATTLE}

The study showed that browse plants as a group seldom if ever contributed a major share of the cattle diet. They achieved greatest importance (on a weight basis) during the early spring and winter (table 1). At these seasons they comprised approximately 16 percent of the total cattle feed.

In the spring, most of the browse plants were grazed to some degree, but no single plant contributed more than 3 to 4 percent of the total forage intake. The amount and kind of browse eaten at this time was quite consistent from day to day and for different years. Sawpalmetto, blackgum, summersweet clethra, and bedstraw St. Johnswort contributed most of the browse-type forage at this season. Intake of browse declined as summer approached, although several of the species were grazed rather consistently. Very little browse was eaten during the early fall.

At the onset of near-freezing weather in late fall or early winter, most herbaceous forage becomes dry and unpalatable. Presumably this tended to increase the consumption of browse. Grazing was confined primarily to evergreen browse plants, of which myrtle dahoon, sweetbay magnolia, sawpalmetto, American cyrilla, and laurel greenbriar were most important (fig. 7). Grazing of those plants during the winter tended to be erratic. Cattle apparently acquired a temporary craving for a particular plant and would confine their grazing to one or two shrubs such as myrtle dahoon or sawpalmetto for several hours. These plants often supplied 25 to 30 percent of the cattle feed for that particular day. Conversely, the cattle would go several days without consuming any appreciable quantities of these plants.

\section{CHEMICAL COMPOSITION OF BROWSE PLANTS}

\section{Crude Protein}

During spring and summer the concentration of crude protein in browse was slightly higher than the average of the total forage intake by cattle (table 2). Since browse plants comprised a considerable portion of the cattle feed at this time, they helped to increase the crude protein level in the cattle diet. Without the help of browse, the crude protein content of the total forage intake would have been less than these data indicate. 


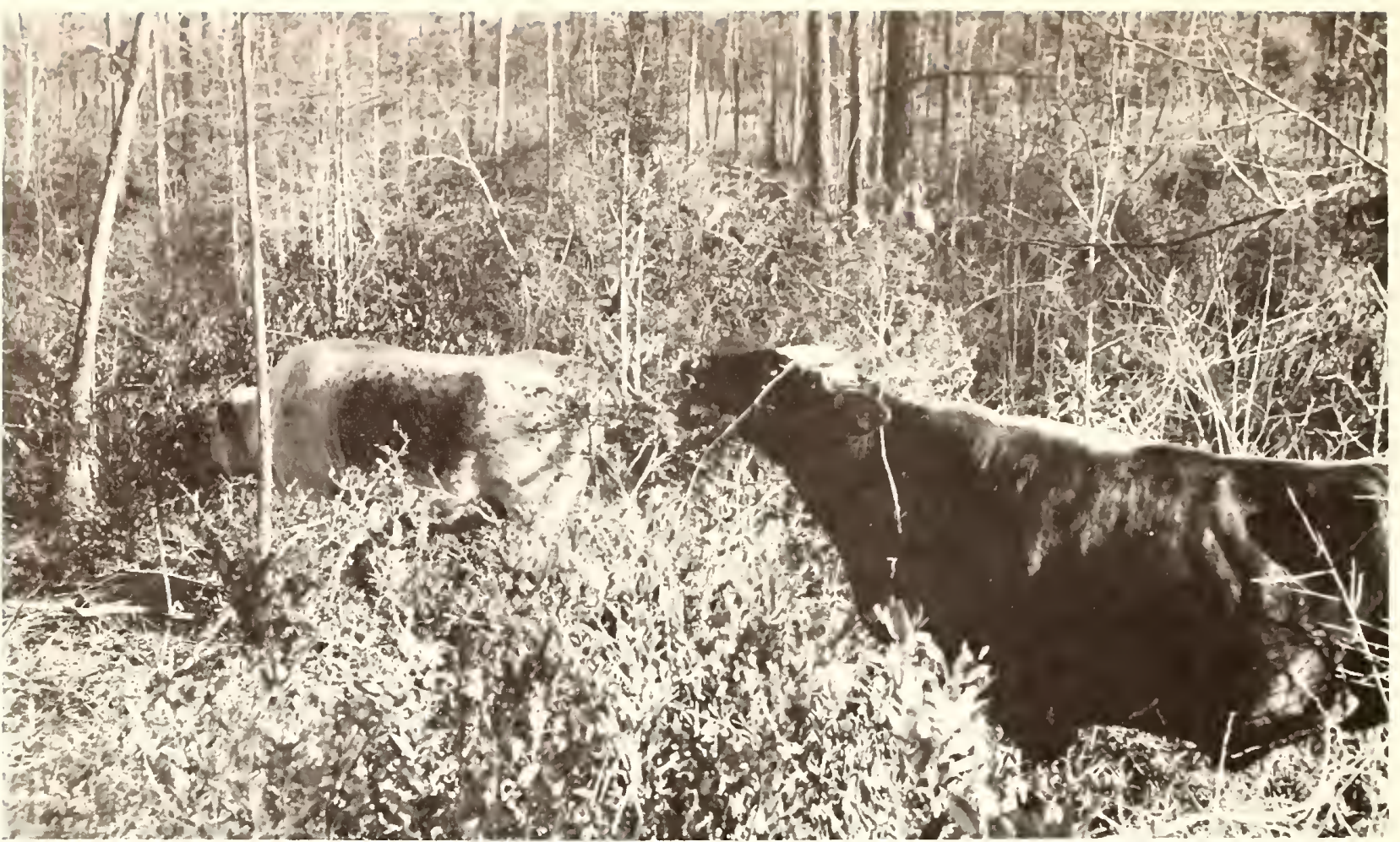

Figure 7.--In the winter cattle move through swamps and lowland areas in search of green feed. Browse contributes a relatively large amount of feed during this time.

Table 2. - - Chemical composition of browse $1 /$ as compared to the total forage intake by cattle $2 /$ (in percent)

\begin{tabular}{|c|c|c|c|c|c|}
\hline \multirow[b]{2}{*}{$\begin{array}{c}\text { Season and } \\
\text { kind of sample }\end{array}$} & \multicolumn{5}{|c|}{ Chemical composition } \\
\hline & $\begin{array}{l}\text { Crude } \\
: \text { protein }\end{array}$ & $\begin{aligned}: & : \\
: \text { Lignin } & \text { Ash } \\
& :\end{aligned}$ & $\begin{array}{l}\text { : Ether } \\
: \text { extract }\end{array}$ & $\begin{array}{l}\text { Cellu- } \\
: \text { lose }\end{array}$ & $\begin{array}{l}\text { : Other } \\
\text { : carbo- } \\
\text { : hydrates }\end{array}$ \\
\hline
\end{tabular}

Spring:

$\begin{array}{lllllll}\text { Browse } & 11 & 21 & 6 & 4 & 17 & 41 \\ \text { Total forage intake } & 10 & 13 & 8 & 2 & 32 & 35\end{array}$

Summer:

\begin{tabular}{|c|c|c|c|c|c|c|}
\hline Browse & 10 & 21 & 4 & 4 & 21 & 40 \\
\hline Total forage intake & 9 & 13 & 9 & 2 & 32 & 35 \\
\hline \multicolumn{6}{|l|}{11} & \\
\hline Browse & 7 & 26 & 3 & 4 & 25 & 5 \\
\hline Total forage intake - & 8 & 12 & 7 & 2 & 34 & 7 \\
\hline \multicolumn{6}{|l|}{ nter } & \\
\hline Browse & 8 & 24 & 4 & 6 & 20 & 38 \\
\hline Total forage intake & 5 & 16 & 6 & 3 & 30 & 0 \\
\hline
\end{tabular}

1) Average chemical composition of all browse plants at the season of year they were eaten by cattle.

2/ A composite sample of all grasses, broadleaved herbs, and browse eaten by cattle. See footnote 3 . 
On the assumption that crude protein of forage should be 8 percent or greater to meet the requirements for any class of cattle (12), most browse plants supplied adequate amounts of this nutrient during the spring and summer. Species such as summersweet clethra, American cyrilla, blackgum, and running oak contained rather liberal amounts (table 3). Sawpalmetto was an exception. During the spring this plant was definitely deficient in crude protein.

Table 3.-- Chemical composition of individual browse plants during the season they were grazed most $1 /$ (in percent)

\begin{tabular}{|c|c|c|c|c|c|}
\hline \multirow{2}{*}{$\begin{array}{c}\text { Season of collection } \\
\text { and species }\end{array}$} & \multicolumn{5}{|c|}{ Chemical composition } \\
\hline & $\begin{array}{l}\text { Crude }: \\
: \text { protein }: \text { Lignin }\end{array}$ & : Ash & $\begin{array}{l}: \text { Ether } \\
: \text { extract } \\
\end{array}$ & $\begin{array}{l}\text { Cellu- } \\
: \text { lose } \\
\end{array}$ & $\begin{array}{l}: \text { Other } \\
: \text { carbo- } \\
: \text { hydrates }\end{array}$ \\
\hline
\end{tabular}

Spring:

Red maple

Red chokeberry

Summersweet clethra

American cyrilla

Bedstraw St. Johnswort

Gallberry

Blackgum

Running oak

Sawpalmetto

Staggerbush

Winter:

Buckwheattree

Myrtle dahoon

Sweetbay magnolia

Laurel greenbriar
11

10

13

13

10

11

13

13

7

10

$\begin{array}{ll}18 & 5 \\ 19 & 6 \\ 26 & 7 \\ 19 & 7 \\ 23 & 2 \\ 17 & 3 \\ 12 & 4 \\ 26 & 4 \\ 21 & 5 \\ 27 & 6\end{array}$

5
3
2
4
9
3
3
3
2
7

16

45

19

43

36

43

34

56

54

36

33

32

18

$\begin{array}{rrrrrr}6 & 22 & 2 & 7 & 15 & 48 \\ 8 & 20 & 3 & 7 & 17 & 45 \\ 10 & 21 & 7 & 8 & 20 & 34 \\ 9 & 30 & 2 & 3 & 20 & 36\end{array}$
ranges.
1/
An average of two or
r more
composite
amples taken from separate

During the fall, average crude protein of browse declined to a submarginal level of 7 percent. But because such meager quantities of browse were eaten at this time, they had little effect on the protein level of the average forage sample.

Browse maintained a fairly high crude protein level of 8 percent during the winter, whereas the average of the cattle diet dropped to a low of 5 percent. Thus, browse plants play a rather significant role in supplying crude protein for cattle grazing forest range at this season. Sweetbay magnolia, myrtle dahoon, and laurel greenbriar were plants highest in crude protein. The evergreen characteristics of these plants account for the fairly high crude protein content as compared to that in the bleached, dry, herbaceous forage. 
Browse was much higher in lignin than the average for composite forage samples (table 2). Lignin in browse ranged from approximately 21 percent during the spring and summer to 26 and 24 percent in the fall and winter as contrasted to the extremes of 12 and 16 percent for total forage intake. Blackgum was lowest (12 percent) and laurel greenbriar highest (30 percent) in this component (table 3 ). Such a high lignin content detracts considerably from the value of browse species because this constituent is practically indigestible and large amounts tend to decrease the digestibility of other nutrients. If taken into the body in appreciable amounts, it seems doubtful whether plants containing large quantities of lignin could be of much benefit to the animal.

Ash

Ash content of browse was generally less than in composite forage samples. This is attributed to the fact that portions of browse collected for chemical analysis usually were well above the ground. They thus avoided sand and dirt in raindrop splatter, which commonly adheres to herbaceous vegetation.

\section{Ether Extract}

Ether extract was fairly high in most of the shrubs and, on the average, was about twice as concentrated as the composite sample of cattle diet. This relatively high amount of ether extract was probably a result of the waxes and resins that form on the outer surface of the leaves of browse. These substances become more concentrated as the plant leaves mature, and thus the amount of ether extract was greater in the winter collections.

\section{Cellulose and Other Carbohydrates}

The more digestible portion of the carbohydrate fraction is composed of cellulose and other carbohydrates. These nutrients are the main source of energy for animals. Browse plants were relatively low in these nutrients, particularly as regards cellulose. Differences between browse and other plants were greatest during the fall and winter. Thus, browse plants are undoubtedly poor sources of energy during the time of year when high energy feeds are required for animals.

\section{MINERAL COMPOSITION OF BROWSE PLANTS}

\section{Major Elements}

Calcium.--Browse serves a very valuable function by furnishing a relatively large amount of calcium. Nearly all browse plants contained more calcium than other components of the forage (table 4) and a greater amount than is required for animal maintenance (12). The only exception was 
sawpalmetto, and this plant contained inadequate amounts during the spring. Calcium content of browse plants was lowest in the spring, it increased during the summer, and remained at a fairly constant level through the fall and winter. Red maple, red chokeberry, summersweet clethra, staggerbush, and blackgum were highest in this element (table 5). In winter, animals selected browse species that were slightly lower in calcium than those eaten in the fall.

Table 4.--Major element composition of browse $1 /$ as compared

$$
\frac{\text { to the total forage intake by cattle }}{\text { (in percent) }}
$$

Season of collection and kind of sample

\begin{tabular}{llll}
$:$ & \multicolumn{3}{c}{ Major element } \\
\hdashline & Calcium & $\vdots$ & Phosphorus \\
\hline
\end{tabular}

Spring:

Browse

0.48

0.15

Total forage intake

Summer:

Browse

Total forage intake

Fall:

Browse

Total forage intake

Winter:

Browse

Total forage intake

$\begin{array}{ll}.57 & .08 \\ .17 & .06\end{array}$

\section{1) Average composition of all browse plants at the season of year} they were eaten by cattle.

2/ A composite sample of all grasses, broadleaved herbs, and browse eaten by cattle. See footnote 3 .

Even though browse contains more than sufficient calcium to meet cattle requirements, these plants do not fully compensate for insufficient quantities in other groups of plants. As a result, the calcium content of the average cattle diet was slightly less than the 0.25 percent recommended for normal growth of a 600 pound steer or heifer (12).

Phosphorus.--Browse possessed greater amounts of phosphorus than other groups of plants during the spring and winter but less during the summer and fall. The average phosphorus content of all browse was on the borderline of or below the 0.15 -percent level required for any class of cattle (12). However, specific species such as red maple, American cyrilla, staggerbush, and running oak contained sufficient phosphorus during the spring. Browse plants grazed during the winter, even though higher in phosphorus than other groups of plants, were very low in this mineral. 
Table 5. - Mineral composition of individual browse plants during the season they were grazed most 1$]$

\begin{tabular}{|c|c|c|c|c|c|c|c|}
\hline \multirow{2}{*}{$\begin{array}{l}\text { Season of collection } \\
\text { and species }\end{array}$} & \multicolumn{2}{|c|}{ Major elements: } & \multicolumn{5}{|c|}{ Minor elements } \\
\hline & $\begin{array}{l}\text { Cal- } \\
\text { cium }\end{array}$ & $\begin{array}{l}\text { Phos- } \\
\text { :phorus }\end{array}$ & $\begin{array}{l}\text { Cop- } \\
\text { per }\end{array}$ & : Iron & $\begin{array}{l}\text { : Man- } \\
\text { : ganese } \\
\end{array}$ & Zinc & Cobalt \\
\hline & $--\underline{P e}$ & cent - - & -- & - Par & ts per mi & llion - & --- \\
\hline \multicolumn{8}{|l|}{ Spring: } \\
\hline Red maple & 0.65 & 0.17 & 9.0 & -- & 485 & -- & 0.14 \\
\hline Red chokeberry & .87 & .11 & 5.6 & 66 & 84 & 26 & .32 \\
\hline Summersweet clethra & .93 & .12 & 10.6 & 81 & 751 & 47 & 9.30 \\
\hline American cyrilla & .30 & .17 & 8.1 & -- & 60 & -- & .09 \\
\hline Bedstraw St. Johnswort & .34 & .10 & -- & -- & -- & -- & -- \\
\hline Gallberry & .38 & .15 & 8.4 & -- & 284 & -- & .12 \\
\hline Blackgum & .65 & .12 & 7.8 & 79 & 366 & 14 & 6.90 \\
\hline Running oak & .51 & .21 & 12.0 & -- & 373 & -- & .29 \\
\hline Sawpalmetto & .09 & .13 & 17.0 & 23 & 100 & 15 & .06 \\
\hline Staggerbush & .66 & .22 & 9.0 & -- & 357 & -- & .12 \\
\hline \multicolumn{8}{|l|}{ Winter: } \\
\hline Buckwheattree & .39 & .05 & 4.0 & -- & 157 & -- & .06 \\
\hline Myrtle dahoon & .62 & .06 & 6.3 & -- & 254 & -- & .12 \\
\hline Sweetbay magnolia & .55 & .10 & 5.0 & 74 & 168 & 27 & .06 \\
\hline Laurel greenbriar & .44 & .07 & 4.7 & -- & 102 & -- & .05 \\
\hline
\end{tabular}

1) An average of two or more composite samples taken from duplicate ranges.

\section{Minor Elements}

Copper. -- Pasturage containing 7.5 p.p.m. (parts per million) of copper is regarded as being healthy (3). On this basis, it was found that most browse plants contain ample amounts of this element during the spring (table 5). Browse was below recommended levels for copper during the winter but remained above 1 to 4 p.p.m., the point where cases of anemia, emaciation, and diarrhea have responded to copper therapy (12). Sawpalmetto, summersweet clethra, running oak, red maple, and staggerbush were particularly high in this element. Blackgum varied considerably, but most samples contained adequate amounts of copper.

Some important forage grasses, pineland threeawn (Aristida stricta Michx.), curtiss dropseed (Sporobolus curtissii [Vasey] Small ex Scribn.), and toothachegrass (Ctenium aromaticum [Walt.] Wood) were collected concurrently and in the same immediate vicinity, as were several of the browse plants. These were analyzed for minor elements and for comparative purposes with several species of browse. As indicated in table 6, browse plants were considerably higher in copper than the grasses, which were apparently on the borderline or deficient in this element. 
Table 6.--Minor element content of browse as compared to native grasses $1 /$

\begin{tabular}{|c|c|c|c|c|c|}
\hline \multirow{2}{*}{ Plant species } & \multicolumn{5}{|c|}{ Minor element content } \\
\hline & Copper & Iron & : Manganese & Zinc & Cobalt \\
\hline \multicolumn{6}{|l|}{ Grasses: } \\
\hline Pineland threeawn & 4.6 & 50 & 177 & 10.2 & 0.05 \\
\hline Curtiss dropseed & 3.9 & 55 & 385 & 10.0 & .02 \\
\hline Toothache grass & 4.5 & 56 & 232 & 13.5 & .04 \\
\hline \multicolumn{6}{|l|}{ Browse: } \\
\hline Summersweet clethra & 10.6 & 55 & 653 & 42.0 & 9.90 \\
\hline Sawpalmetto & 18.1 & 23 & 97 & 14.9 & .07 \\
\hline Blackgum & 6.3 & 61 & 430 & 12.0 & 5.70 \\
\hline
\end{tabular}

1) Analysis of single composite samples taken from one range unit in June, 1953.

Iron. - - Although the iron requirement of cattle is not definitely known, the amount in most feeds is adequate (11). Browse plants were similar to grasses in this element. Since cattle grazing the experimental ranges have shown no evidence of iron deficiency, it is presumed that native forage contains adequate amounts.

Manganese. - -Only traces of manganese are required for cattle. In other studies (12) heifers fed high energy rations containing 6 p.p.m. of manganese subsisted through the gestation period and gave birth to normal calves. According to this standard, all browse and the three grasses contained more than ample amounts of this element.

Zinc. - - Zinc is demonstrably essential to animal life but no evidence of deficiency has been observed with cattle. Although standards are not available for comparison, browse plants of this study probably contained ample amounts.

Cobalt.-- Cobalt-deficient forage contains from 0.01 to 0.07 p.p.m., whereas good forage generally contains from 0.07 to 0.30 p.p.m. (1, 10). Thus, several browse species and the three grasses tested were probably deficient in cobalt. The two plants which stand out as having an abundance of cobalt were blackgum and summersweet clethra (tables 5 and 6). During the spring and summer these plants probably supplied enough cobalt to compensate for the small amounts in the grasses. There is a strong possibility that the average forage intake was deficient in this mineral during the winter. However, it is quite likely that the cattle stored enough of this element in their bodies during spring and summer to compensate for forage deficiencies during the winter.

Little is known of the influence of minor elements on grazing habits. Cattle grazing sawpalmetto throughout the year were apparently in search of some element, for the texture or major nutrients of palmetto are notattractive; 
on the contrary, the leaves are tough and fibrous and low in crude protein and phosphorus. The only outstanding feature of sawpalmetto was its high copper content, and it seems reasonable, therefore, that abundance of copper contributed to the selection of this plant by grazing cattle.

A somewhat comparable situation existed in regard to cobalt. Summersweet clethra and blackgum contained an abundance of this element, but being deciduous they were not grazed during late fall and winter. With the advent of spring, young shoots and leaves of this species were sought out rather consistently by cattle and contributed materially to intake of cobalt.

\section{SUMMARY}

Browse plants are abundant and make prolific growth in the coastal plain forest ranges of Georgia. A description of the main browse plants, an assay of their nutritional attributes, and estimates of contributions to cattle diet are presented.

Each of the 14 described plants contributed 1 percent or more to the total cattle diet sometime during the year. In all, they made up about 16 percent of the total forage intake during the winter, when other green forage was scarce. Approximately the same proportion was consumed in the spring, when succulent young shoot and leaf growth was abundant. During the summer and early fall only small amounts were eaten.

On a year-round basis, sawpalmetto was grazed more than any other species. Other important browse plants were myrtle dahoon and sweetbay magnolia during the winter, bedstraw St. Johnswort during late winter and early spring, and blackgum and summersweet clethra in the spring.

Crude protein of browse plants was slightly higher than the average amount in cattle diet during spring and summer, slightly lower in the fall, but considerably higher during the winter. Summersweet clethra, American cyrilla, blackgum, and running oak contained greatest amounts of this nutrient. Most browse plants contained adequate amounts for cattle during the spring but were on the borderline or deficient during the winter.

Lignin content of browse eaten by cattle varied from 21 percent in summer to 26 percent in winter. The high content of this practically undigestible component detracted from the value of most browse.

Ash content of browse was generally less than the composite forage sample. The reverse was true of ether extract.

Browse was relatively low in the more digestible portion of the carbohydrate fraction and, therefore, low in energy.

More than adequate amounts of calcium were found in several browse plants. However, amounts were not sufficient to compensate for deficiencies in other groups of plants. 
Phosphorus content of browse differed in small amounts from other groups of plants. Red maple, American cyrilla, staggerbush, and running oak satisfied cattle requirements for phosphorus during the spring but other plants contained inadequate amounts.

Most browse plants provided ample quantities of copper during the spring and apparently enough during the winter to prevent deficiency symptoms in cattle. Sawpalmetto contained large amounts of this mineral, followed in order by running oak, summersweet clethra, staggerbush, and red maple. Several native grasses were apparently deficient in copper.

None of the browse plants appeared to be deficient in iron or zinc; they contained more than adequate amounts of manganese.

Blackgum and summersweet clethra were exceptionally high in cobalt. Enough was probably present to compensate for the low amounts in other groups of plants. Other browse species were on the borderline or deficient in this element for most of the year.

Presumably, the high copper content of sawpalmetto and the cobalt content of summersweet clethra and blackgum induced grazing of these plants.

\section{LITERATURE CITED}

(1) Askew, H. O., and Maunsell, P. W.

1937. The cobalt content of some Nelson pastures. New Zealand Jour. Sci. and Technol. 19: 337-42.

(2) Association of Official Agricultural Chemists

1950. Official methods of analysis. Ed. 7, 910 pp., Washington, D. C.

(3) Bennetts, H. W., Beck, A. B., Harley, R., and Evans, S. T.

1941. Falling disease of cattle in south-west Australia.

Australian Vet. Jour. 17: 85-93.

(4) Crampton, E. W., and Maynard, L. A.

1938. The relation of cellulose and lignin content to animal feeds.

Jour. Nutrition 15: 383-395.

(5) Davis, R. E., and Miller, C. O.

1939. Partition of the less easily digested carbohydrate complex of forages. Jour. Industrial and Engin. Chem., Anal. ed. 11:651-652.

(6) Gregory, R. L., Morris, C. J., and Ellis, G. H.

1951. Some modifications in the ortho-nitrosocresol method for the determination of cobalt. Jour. Assoc. Off. Agr.

Chemists 34: 710-716. 
(7) Kelsey, H. P., and Dayton, W. A.

1942. Standardized plant names. Ed. 2, 675 pp. J. Horace McFarland Company, Harrisburg, Penna.

(8) Little, E. L., Jr.

1953. Check list of native and naturalized trees of the United States. U. S. Dept. Agr. Agricultural Handbook No. 41, $472 \mathrm{pp}$.

(9) Van Dersal, W. R.

1938. Native woody plants of the United States. U. S. Dept. Agr. Misc. Pub. 303, 362 pp.

(10) McNought, K. J.

1938. Cobalt content of North Island Pastures. New Zealand Jour. Sci. and Technol. 20: 14-30.

(11) Morrison, F. B.

1949. Feeds and feeding. Ed. 21, 1207 pp. Morrison Publishing Co., Ithaca, N. Y.

(12) National Research Council

1950. Recommended nutrient allowances for beef cattle. (Revised) $37 \mathrm{pp}$. Washington, D. C.

(13) Parks, R. Q., Hood, S. L., Hurwitz, C., and Ellis, G. H.

1943. Quantitative microdetermination of twelve elements in plant tissue. Jour. Industrial and Engin. Chem., Anal. ed. 15: 527-533.

(14) Society of American Foresters

1940. Forest cover types of the Eastern United States. 39 pp. Washington, D. C. 

- national agricultural librapy

1022590068 